elSSN: 09748369, www.biolmedonline.com

\title{
Effect of malathion on liver ache activity of mice
}

\author{
*Varsha Wankhade, ${ }^{1}$ AR Malu, ${ }^{2}$ SP Pawar \\ *Department of Zoology, Pune University, Pune, Maharashtra, India. \\ ${ }^{1}$ Department of Zoology, Arts and Science college, Aurangabad, Maharashtra, India. \\ ${ }^{2}$ Department of Zoology, Govt. Institute of Science, Nagpur, Maharashtra, India.
}

*Corresponding Author: varsha2w@rediffmail.com

\begin{abstract}
An experiment was conducted to study the effect of malathion toxicity on acetylcholinesterase activity in mice liver. Mature mice were exposed to different doses of malathion for different time period. On dissections, enzymatic estimations were done for each exposure period. It was found that, malathion inhibited the acetylcholinesterase activity in mice liver. The maximum period of exposure was upto 30 days. The degree of inhibition increased upto 4 days of exposure period but declined later on. There was maximum recovery of $A C h E$ activity by $30^{\text {th }}$ day of exposure. These findings indicate that the continuous and prolonged exposure to sublethal dose of malathion resulted in the recovery of AChE activity.
\end{abstract}

Keywords: Malathion, Mus musculus, Liver, AChE.

\section{Introduction}

Malathion is most widely used organophosphate insecticide through out the world. It is used to control the pests of agriculture crops, ornamentals, green houses, live stocks, stored grains,forests, buildings and gardens. Contributing to its popularity is malathion's low acute mammalian toxicity. But like DDT and other pesticides that have been found to cause irreparable damage to human and environmental health, malathion may pose a greater risk than the product lable would lead one to believe. The toxicity of malathion is compounded by its metabolites and contaminants. Malaoxon, the metabolites produced by the oxidation of malathion in mammals, insects, plants is the primary source of malathion's toxicity and it is 40 times more acutely toxic than malaoxon.

Malathion is organophosphorous pesticide extensively used to control a wide range of sucking and chewing pests of field crops, fruits and vegetables. It has many structural similarities with naturally occurring compounds, and their primary target of action in insects is the nervous system; it also inhibit the release of the acetylcholonesterase at the synaptic junction(Cabello et al 2001). Acetylcholinesterase plays a key role in the control of nerve excitability at post synaptic sites. Malathion is found to inhibit the acetylcholinesterase. Inhibition of liver acetyl cholinesterase (AChE) activity is generally regarded as an useful indicator of poisoning by organophophorous pesticides. Mice have been selected for present study as they have physiological systems and responses similar to those of man. They have also a remarkable genetic similarities to human.

\section{Materials and Methods}

Only the healthy pairs of mice were housed in the separate cages. The temperature of house was maintained in the range of $20^{\circ}$ to $25^{\circ} \mathrm{c}$. The animals were fed on commercially available pellet diet. Mature and healthy mice of either sex weighing between 30 to $40 \mathrm{gm}$ were divided into two groups. Animals in each group were maintained on specific diet. The animals of group I were fed a stock diet used as a control. Animals from group II were given malathion orally $(80.6 \mathrm{mg} / \mathrm{kg}$ body weight per day) in a suspension made in distilled water. Mice were selected for sublethal group exposed to only control diet and sacrificed at the end of the experimental period of thirty days. (20 mice).

Group II- mice were exposed to sublethal concentration of malathion i.e.1/3 of Lc 50/96h.

Group II was further divided into five subgroups, each of 4 mice as under; depending on the malathion exposure period.

GI-2days, GII-4days, GIII-8days, GIV15days, GV-30days.

After the start of experiment, each subgroup at respective treatment period was sacrificed and was used for enzyme analysis. 
Before this, lethal toxicity tests were carried out for four different concentrations of the malathion.

\section{Enzyme extraction}

Pesticide treated mice were killed by cervical dislocation and were dissected. Liver was taken out, washed with $0.9 \% \mathrm{NaCl}$ and homogenized in $0.9 \% \mathrm{NaCl}$. Estimation for acetylcholinesterase was done by Ellman method (1961).

\section{Statistical analysis}

Statistical analyses were performed using analysis of variance (ANOVA), followed by post- hoc (Bonfferroni) least significant difference testing where $P<0 \times 05$ on ANOVA. Data were presented as mean $\pm \mathrm{SD}$ and $P<0 \times 05$ was considered statistically significant. All calculations were made using SPSS for Windows $10 \times 0$ program.

\section{Results}

Michaelis Menten plots drawn by using data regarding the effect of varying substrate concentration on initial velocity (v) of liver AChE from control and malathion exposed mice for 2 , $4,8,15$ and 30 days of exposure period are shown in table1.

Table 1: Effect of malathion on liver AChE activity of mice

\begin{tabular}{|c|c|c|c|}
\hline $\begin{array}{c}\text { Exposure period } \\
\text { (in days) }\end{array}$ & Vmax $\mathbf{E S D}$ & $\mathbf{K m} \pm \mathbf{S D}$ & $\mathbf{V m a x} / \mathbf{K m}$ \\
\hline Control & 0.084 & 0.240 & 0.278 \\
& \pm 0.0032 & +0.0025 & 0.146 \\
\hline 2 days & 0.060 & $0.410^{*}$ & $(-47.49)$ \\
\hline 4 days & +0.0041 & +0.0018 & $0.120^{\star *}$ \\
& 0.054 & 0.448 & $(-56.84)$ \\
\hline 8 days & +0.0027 & +0.0033 & 0.197 \\
& 0.075 & 0.380 & $(-29.14)$ \\
\hline 15 days & +0.0037 & +00021 & 0.230 \\
& $0.0082^{*}$ & 0.355 & $(-17.27)$ \\
\hline 30 days & +0.0037 & +0.0021 & 0.255 \\
& 0.087 & 0.340 & $(-8.26)$ \\
\hline
\end{tabular}

Vmax expressed as $\mathrm{A} / 0.1$ protien/min.

$\mathrm{Km}$ expressed as $\mathrm{mM}$ of ATChl

${ }^{*}=p<0.05,{ }^{* *}=p<0.01,{ }^{* * *}=p<0.001$

Parenthetic values are \% change from control.

Maximum decrease in $\mathrm{Vmax} / \mathrm{Km}$ ratio has been observed after 4 days exposure to pesticide treatment while minimal decrease in the same ratio has been observed at the end of 30 days exposure. Vmax/Km ratio decrease upto 4 days of exposure to malathion treatment . After which gradual uplift in $\mathrm{Vmax} / \mathrm{Km}$ ratio takes place upto 30 days exposure to malathion.

\section{Discussion}

Eserine, parathion and malathion are cholinesterase inhibitors responsible for the hydrolysis of body choline esters, including acetylcholine at cholinergic synapses. Acetyl cholinesterase activity decreased in the serum of rats. The results indicate that organophosphorous pesticides induce changes in the epithelium of mammary gland influencing the process of carcinogenesis, and such alterations occur at the level of nervous system by increasing the cholinergic stimulation (Cabello et al 2001).

Study clearly indicate that malathion used as a commercial product i.e. containing malaoxon and isomalathion, can be considered as a genotoxic substance in vitro. Malathion may also produce DNA disturbances in vivo, such as DNA breakage at sites of onchogenes or tumour suppressor genes, thus playing a role in the induction of malignancies in individuals exposed to this agent. Therefore, malathion can be 
regarded as a potential mutagen/carinogen and requires further investigation (Blasiak at al 1999). In vitro detoxificatio of the organophosphate (OP) insecticides paraoxon,chlorpyrifosoxon and malaoxon has been investigated in human serum (Sams and Mason1999).

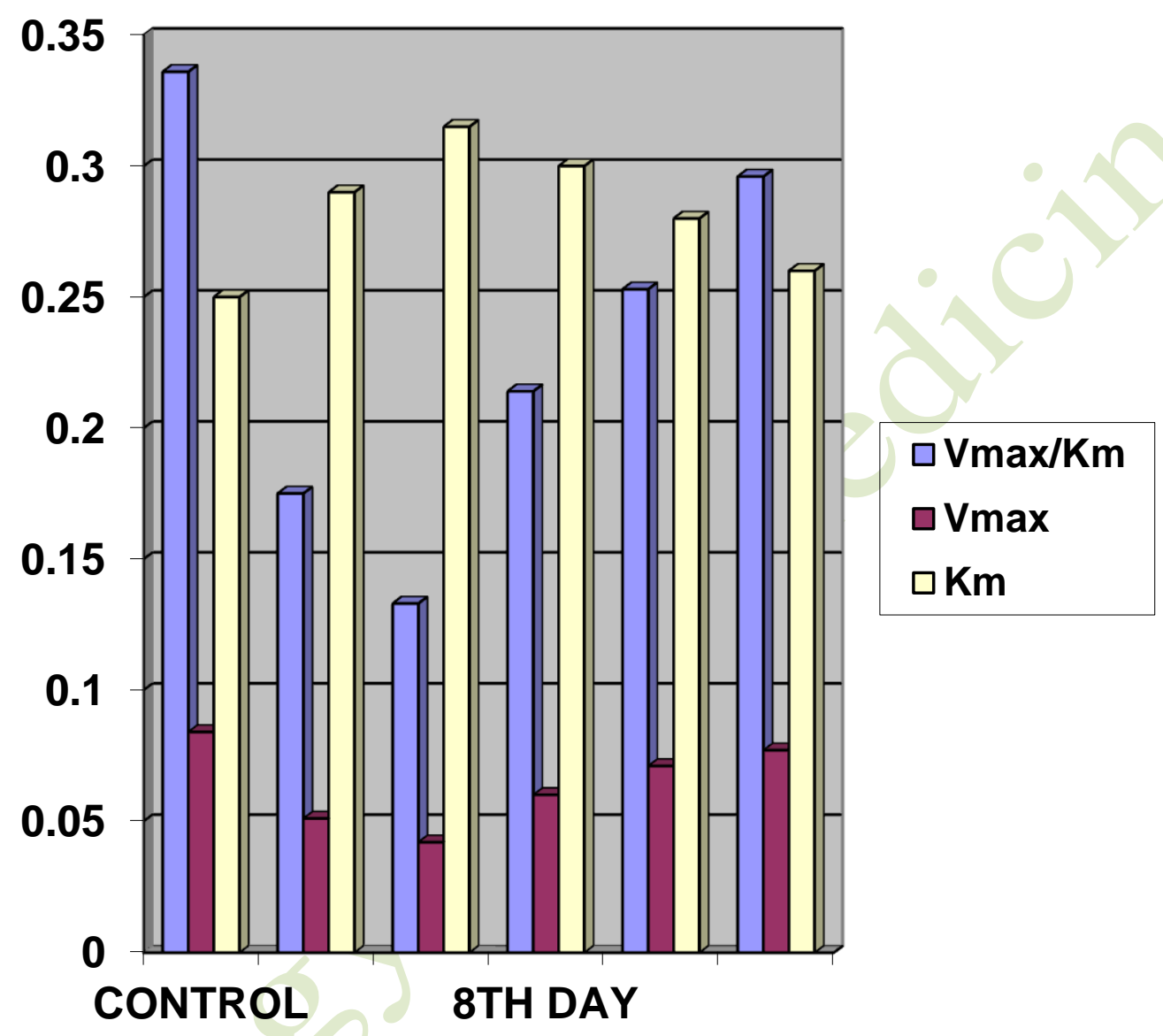

Fig 1: Graphical representation of effect of malathion on liver AChE activity of mice Vmax expressed as A/0.1 protien/min. Km expressed as mM of ATChl

Mineau reported that after exposure to carbamate and organophosphate cholinesterase activity in wild birds decreased (Mineau,1993). Shakoori et al reported $84 \%$ inhibition in Tribolium castanem due to sublethal doses of cypermethrin (Shakoori et al 1995). Gard and Hooper reported that organophosphors and carbamate exert their effects by binding to and inhibiting the acetylcholinesteraase enzyme at nerve synapses (Gard snd Hooper 1995). Organophosphorous compounds may induce oxidative stress leading to generation of free radicals and alterations in antioxidant and scavengers of oxygen free radicals (OFRs). The effect of subchronic exposure to malathion in the production of oxidative stress was evaluated in male Winstar rats (Maryam Akhgari etal 2003). Administration of malathion $(100,316,1000,1500$ ppm) for 4 weeks increased catalasse (CAT), superoxide dismutase (SOD) activities as well as maalondialdehyde (MDA) concentration in red blood cells (RBC) and liver. 
However,acetylcholinesterase (AchE ) and cholinesterase (CHE)activities were decreases in these samples. The increase in RBC and liver peroxidation correlated well with the inhibition in RBC AchE and liver CHE activities (Maryam Akhgari et al 2003). Azmi et al (1999) studies the effects of tetranortriternoides (Neem product SDS) and deltamethrin (pyrethroid) on phosphomonoesterase activity in Cyprinus (common carp) and reported enzyme inhibition under the effect of these pesticide (Azmi et al 1999). The result demonstrate that the magnitude of AchE inhibition in peripheral tisues does not accurately reflect the central inhibitory effects of malathion on AchE activity in specific brain regions (Banasik 2003). Burgees et al (1999) observed that a organophosphate insectiside reduced cholinesterase activity in birds (Burgees1999). Taylor et al reported that a sublethal dose of field grade malathion (0.01 $\mathrm{mg} / \mathrm{g}$ ) lowered brain cholinesterase levels by $22 \%$ and 175 , respectively (Taylor et al 1999). Parson et al observed effect of organophosphate and carbamate on non target wild animals and these pesticides inhibited cholinesterase activity(Parson et al 2000). The potential use of acetylcholinesterase (Ache) and metallothionein (MT) responses as biomarker of organophosphorous (OPs) and trace metal were assessed in fish Seriola dumerilli brain Ache was significantly inhibited after 2 nd 7 days of malathion exposure (Jebali, 2006). Khan studied the effect of permethrin and biosal in the Indian garden lizard and reported that after treatment with permethrin cholinesterase levels decreased by up to $17 \%$ and $19 \%$ in the kidney and $18 \%$ and $24 \%$ in the liver (Khan et al, 2002). The study indicates that malathion inhibited the AchE activity in brain of mice (Wankhade et al 2008). In present study, we also found the decrease in the activity of acetylcholinesterase after the exposure of mice to malathion. Activity of acetylcholinesterase was recovered later.

\section{Conclusion}

Michaelis-Menten plot drawn by using data regarding the effect of various substrate concentrations on initial velocity ( $v$ ) of liver AChE from control and malathion exposed mice for $2,4,8,15$ and 30 days of exposure period are shown in table 1. Maximum decrease in Vmax $/ \mathrm{Km}$ ratio was observed after 4 days of exposure period to malathion treatment while minimum decrease in the same ratio was observed at the end of 30 days of exposure period. $\mathrm{V} \max / \mathrm{Km}$ ratio decreased upto four days of exposure to malathion. After which gradual uplift in $\mathrm{V}$ max/ $\mathrm{Km}$ ratio took place up to 30 days of exposure to malathion.

These findings indicates that the continuous and prolonged exposure to sublethal dose of malathion resulted in the recovery of AChE activity.

\section{References}

Azmi,M.A.,Jahan,S.,Naqvi, S.N.H.,Tabassum,R., Khan M.F. and Akhar,K., 1999. Effect of tetranortriterpenoids (Neem products SDS) and deltramethrin (pyrethroid) on phosphomonoesterases activity in Cyprinus carpio (commom carp).,National Academy of Science Letters, 22: 130-134.

Banasik M.; Stedeford T.;Persad A.S.;Ueda K.;Tanaka S.; Muro-Cacho C Harbison R.D.Selective Inhibition of Acetylcholinesterase in the Cerebellum and Hippocampus of Mice Following an Acute Treatment with Malathion. Journal of Enzyme Inhibition and Medical Chemistry, Volume 18, Number 6, December 2003, pp 551-555(5).

Blasiak J., P Jaloszynski , A Trzeciak K Szyfter. In vitro studies on the genotoxicity of the organophosphorous insecticide malathion and its two analogues. Mutation Research 1999 Sep 30; 445(2): 275-83.

Burgees,N.M.,Hunt K.A.,Bishop, C. and Weseloh,D.V., 1999. Cholinesterase inhibition in tree swallow (Tachycineta and eastern blue bird (Sialia sialis) exposed bicolor) to organophosphorus insecticides in apple orchards in Ontario, Canada. Environmental Toxicology and Chemistry, 18; 708716.

Cabello G,M. Valenzuela, A Vilaxa, V Duran , I Rudolph, N Hrepic, G Calaf. A rat mammary tumor model induced by the organophosphorous pesticides parathion and malathion possibly through acetylcholinesterase inhibition. Environmental Health Perspectives 2001 May; 109 (5):471-9.

Gard N.W. and Hooper, M.J.,1995. An assessment of potential hazards of pesticides and environmental contaminations in: Ecology and Management of Neotropical Migratory Birds. Oxford University Press, New York ,294-307.

Jebali J., M. Banni, H. Guerbej, E. A. Almeida, A. Bannaoui and $\mathrm{H}$. Boussetta. Fish Physiology and Biochemistry Volume 32, Number 1/March,2006.9398.

Khan M.Z. 2002. Camprison of induced effect of pyrethroid (permethrin )with phytopesticide (biosal) on cholinesterase activity against lizard Calotes 
versicolor Daudin (Agamidae). Journal of Natural History and Wildlife 1:15-20.

Khan,M.Z.,Naqvi, S.N.H.,Khan, M.F.,Tabassum, R. Ahmad, J. and Farina F. 2002. Induced effect of biosal on GOT and GTP in wildlife species of agama lizard Calotes versicolor. Pakistan Journal of Biological Sciences 4:611-612.

Maryam Akhgari ,Mohammad Abdollahi, Abbas Kebryaeezadeh, Ruhollah Hosseini,Omid Sabzevari. Biochemical evidence for free radical-induced lipid peroxidation as a mechanism for subchronic toxicity of malathion in blood and liver of rats. Human and Experimental Toxicology 2003 Apr ;22(4): 205-11.

Mineau P.,1993. The hazard of carbofuran to birds and other vertebrate wildlife. Technical Report Series No.177 Canadian Wildlife Service.

Parsons ,K.C.,Matz, A.C.,Hooper,M.J. and Pokras, M.A., 2000.Monitoring wading bird exposure to agricultural chemicals using serum cholinestrases activity. Environmental Toxicology and Chemistry, 19:1317-1323.

Same $\mathrm{C}, \mathrm{H} \quad \mathrm{J}$ Mason. Detoxification of organophosphates by A-esterases in human serum. Human and Experimental Toxicology 1999 Nov; 18 (11):653-8

Shakoori,A.R., Khalique,F. and Saleem,M.A., 1995. Effects of a synthetic pyrethroid Ripcord 10 EC on esterase of Tribolium castaneum. Pakistan Journal of Zoology 27:165-174.

Taylor,S.K.,Wildlife,E.S.and Mills, K.W.,.,1999. Effects of malathion on disease susceptibility in woodlouse's toads. Journal of Wildlife Diseases, 35: 536-541.

Wankhade Varsha, K .M.Kulkarni and A.R. Malu 2008. Effect of Malathion Toxicity on Liver Ache Activity of Mice. Environment and Ecology (2) June 2008, 494-496. 